\title{
Statistical Analysis and Classification of Pollutants in the Nokoué Lake (Benin)
}

\author{
Deguenon Judicael, Deguenon Jean and Dumitriu Cristian Ștefan
}

\begin{abstract}
The water quality of a lake is an important factor for human health. Since the pollution level of the Nokoué Lake (Benin) became a concern, the present study was carried out to better understand and manage the quality of the surface water of this lake, to reduce the risks to damage the population health and the ecosystem equilibrium. The objective of the present work is the statistical study of the pollutants concentration data using Principal Component Analysis (PCA) and clustering. The concentration of five pollutants, namely $\mathrm{NO}_{3}^{-}, \mathrm{NH}_{4}^{+}, \mathrm{NT}$ (total nitrogen), $\mathrm{PO}_{4}^{3-}$, and total phosphates (PT) were sampled on thirty-three sites of the Nokoué Lake and analyzed. Three principal components have been selected and the sites have been grouped in three clusters, one of them containing only the sites on Cotonou.
\end{abstract}

Keywords - clustering, Nokoué Lake, PCA, pollutants, surface water

\section{INTRODUCTION}

Nowadays, environmental pollution became a stringent issue to be solved all over the world, in the context of industrial development [1] - [3]. The quality of water is of paramount importance for human life and the development of economic activities, but many countries are facing water scarcity, more accentuated in some regions because of climate change. Thus, many studies have been devoted to the analysis and modeling of the evolution of the water parameters and to find solutions for cleaning the industrial waters [4] $-[10]$.

Multivariate statistical analysis has been proved to be a valuable instrument for classifying the water parameters and to assess the water quality, as a preliminary stage of taking decisions to conserve the properties of this valuable resource [11] - [13].

It is in this perspective that this work proposes to analyze some pollutants of the surface water of Nokoué Lake by applying PCA (Principal Component Analysis) and clustering.

\section{STUDY DATA AND METHODOLOGY}

With a surface of $150 \mathrm{~km}^{2}$, the Nokoue Lake is located in the South-East of Benin, between the parallels $2^{\circ} 24$ 'and $2^{\circ} 37^{\prime}$ North and the meridians $6^{\circ} 23^{\prime}$ and $6^{\circ} 28^{\prime}$ East. It extends over the departments of the Atlantic, Littoral, and Ouémé, and is limited to the 
north by the Ouémé River, the Sô River, to the south by the city of Cotonou, to the west by the plateau of Abomey-Calavi, and the east by the Porto-Novo Lagoon. Nokoué Lake is connected to the Atlantic Ocean by the Cotonou channel and to the Totchè channel by the Porto-Novo Lagoon.

With an average length of $20 \mathrm{~km}$ to the east-west direction and a width of $11 \mathrm{~km}$ in its north-south direction, the average depth of Lake Nokoué is $1.4 \mathrm{~m}$ [12]. The Ouémé River is the main freshwater tributary of Lake Nokoué. Finally, let us remember that Lake Nokoué communicates to the north with the Sô and Ouémé deltas via large floodplains.

Characterized by a weak flood from May to June, the Nokoué Lake experiences a high rainy season in the south of Benin, a strong flood from September to November (due to the great rainy season in the North and the inflows from the Ouémé river), and a period of low water from December to March. Note that the duration of the floods varies, depending on whether the Cotonou channel is closed or open and on the rainfall amount [13].

The flow of the Sô River starts in August and ends in mid-November. During this same period, the basin housing the Nokoué Lake is characterized by a variation of the water level depending on the abundance of river inputs upstream of the river. The monthly average water levels from $0.64 \mathrm{~m}$ in January to $1.4 \mathrm{~m}$ in October [12].

The study has been performed on the series containing the concentrations of water parameters. The samples have been collected from thirty-three sites of the Nokoué Lake in 2017 by Dr. Firmin Adandedji at the Laboratory of the National Institute of Water (INE) from the University of Abomey-Calavi (UAC), Benin.

We decided to focus on data analysis and correlation because of the quantitative complexity of the data. For this aim, the Principal Component Analysis [14] has been performed and the most relevant components have been detected.

When studying a large number of quantitative variables simultaneously (for example 4), how do you make a global graph? The difficulty arises from the fact that the individuals studied are no longer represented in a plane (space of dimension 2) but in a space of greater dimension. The goal of the ACP is to return to a smaller space with the least possible distortion of reality. The aim is to obtain the most relevant summary possible of the initial data [14].

Therefore, the grouping of the water parameters in a small dimensional space. Dimensions are based on similarities in categories. The variance-covariance matrix or the correlation matrix will allow us to produce a relevant summary because it is essentially the analysis of the dispersion of the data considered. Interpreting graphs allows us to understand the structure of the data being analyzed. This interpretation will be guided by several numerical and graphical indicators which will help us to make the most accurate and objective interpretation possible [14].

In this work, individuals are the different sites for sampling pollutant concentrations. The PCA variables are the concentrations of each pollutant. PCA is performed with the reduced centered matrix formed by the individuals (sites) on the rows and the variables (concentrations) in the columns.

Finally, the sites are grouped in clusters, using hierarchical clustering [15].

Data were analyzed with the R software version 4.0.2 using the FactoMineR package [16]. For a deep insight on these techniques, the reader may access [15, 16]. 


\section{RESULTS AND DISCUSSION}

Table 1 shows the correlation matrix, characterizing the relationship between couples of variables. From Table 1 it results that:

- the pairs of variables $\left[\mathrm{NH}_{4}^{+}\right]$and $[\mathrm{NT}],\left[\mathrm{PO}_{4}^{3-}\right]$ and $[\mathrm{NT}] ;\left[\mathrm{NH}_{4}^{+}\right]$and $\left[\mathrm{PO}_{4}^{3-}\right]$,

$\left[\mathrm{NH}_{4}^{+}\right]$and $[\mathrm{PT}] ;[\mathrm{NT}]$ and $[\mathrm{PT}] ;\left[\mathrm{NO}_{3}^{-}\right]$and $[\mathrm{PT}]$ are weakly correlated;

- the pair $[\mathrm{NT}]$ and $\left[\mathrm{NO}_{3}^{-}\right]$is very strongly positively correlated.

Table. 1. Correlation matrix

\begin{tabular}{|c|c|c|c|c|c|}
\cline { 2 - 6 } \multicolumn{1}{c|}{} & {$\left[\mathbf{N O}_{3}^{-}\right]$} & {$\left[\mathbf{N H}_{\mathbf{4}}^{+}\right]$} & {$[\mathbf{N T}]$} & {$\left[\mathbf{P O}_{4}^{3-}\right]$} & {$[\mathbf{P T}]$} \\
\hline$\left[\mathbf{N O}_{3}^{-}\right]$ & 1 & -0.45 & 0.80 & 0.12 & 0.09 \\
\hline$\left[\mathbf{N H}_{4}^{+}\right]$ & -0.45 & 1 & -0.18 & -0.18 & 0.11 \\
\hline$[\mathbf{N T}]$ & 0.80 & -0.18 & 1 & -0.07 & 0.05 \\
\hline$\left[\mathbf{P O}_{4}^{3-}\right]$ & 0.12 & -0.18 & -0.07 & 1 & 0.33 \\
\hline$[\mathbf{P T}]$ & 0.09 & 0.11 & 0.05 & 0.33 & 1 \\
\hline
\end{tabular}

Table 2 presents the eigenvalues, their percentages (calculated compared to the total of the eigenvalues), and the cumulated variances, while Figure 1 shows the eigenvalues diagram.

Table. 2. Eigenvalues and inertia

\begin{tabular}{|c|c|c|}
\hline Eigenvalues & Variances (\%) & Cumulated variances (\%) \\
\hline 2.016 & 40.32 & 40.32 \\
\hline 1.322 & 26.44 & 66.75 \\
\hline 1.000 & 19.80 & 86.55 \\
\hline 0.526 & 10.53 & 97.08 \\
\hline 0.146 & 2.92 & 100 \\
\hline
\end{tabular}

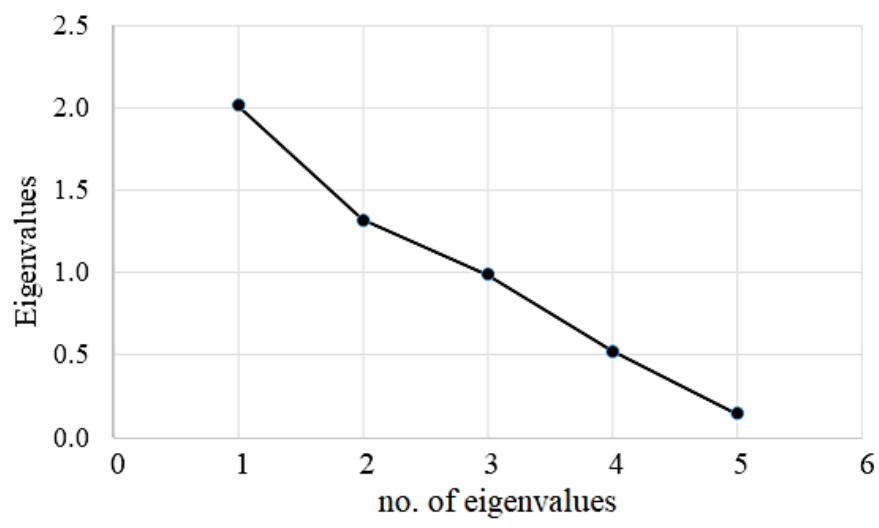

Fig. 1. The eigenvalues diagram

Three principal components are selected, based on the eigenvalues and the cumulated variance explained $(88.55 \%)$. Therefore, the projections of the individuals (sites) on the factorial plan $(1,2)$ and $(1,3)$ are represented in Figure 2 and Figure 3. These sites are characterized by the same variation in the physicochemical parameters, being located in the same area. 
sciendo $_{58}$ Ovidius University Annals Series: Civil Engineering, Year 23, 2021

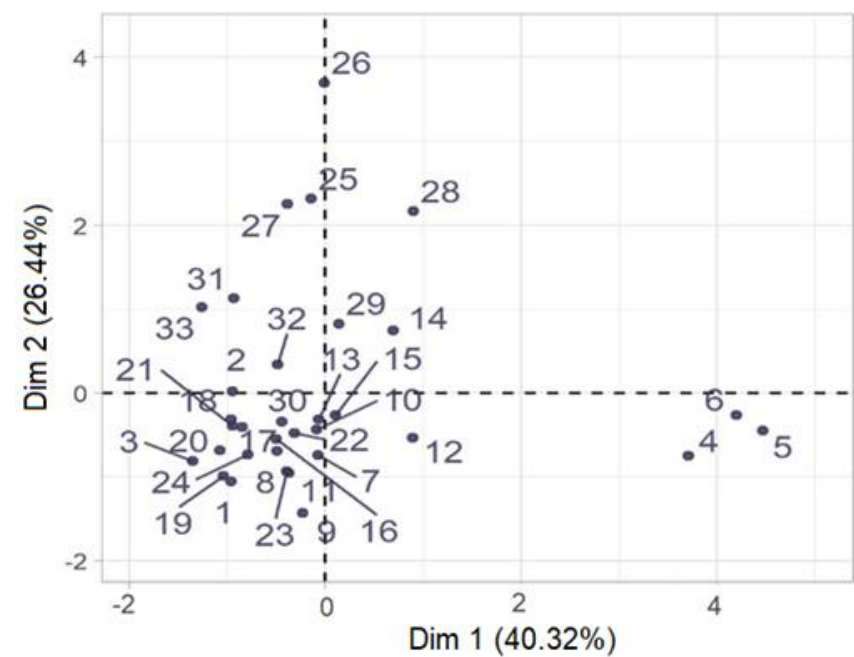

Fig.2. Representation of individuals (sites) in the factorial plane $(1,2)$

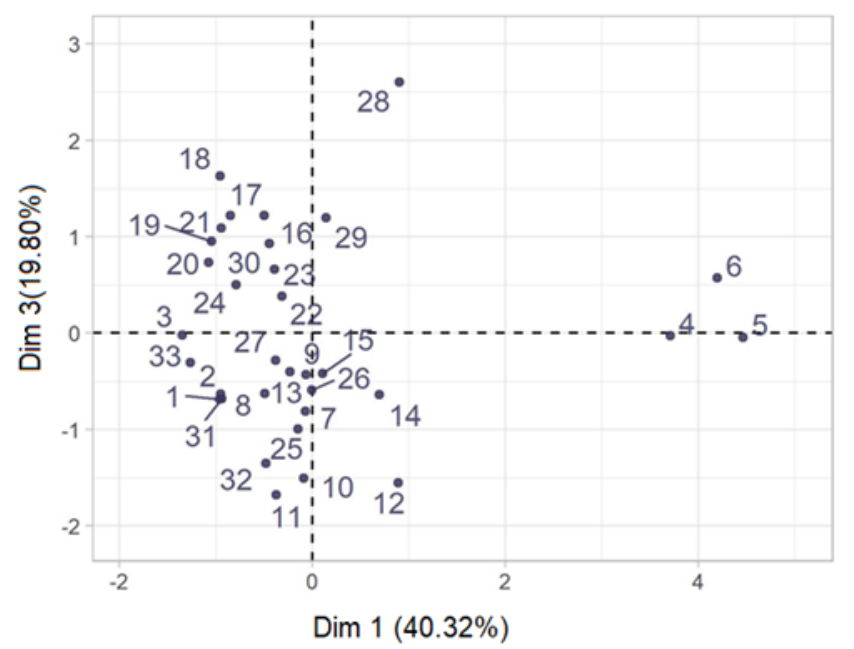

Fig.3. Representation of individuals (sites) in the factorial plane $(1,3)$

Table 3 contains the coordinates of the factorial variables and Figure 4, the representation of variables in the factorial plane $(1,2)$.

Table 3. The coordinates of the factorial variables

\begin{tabular}{|c|c|c|c|}
\hline & $\boldsymbol{F}_{\mathbf{1}}$ & $\boldsymbol{F}_{\mathbf{2}}$ & $\boldsymbol{F}_{\mathbf{3}}$ \\
\hline$\left[\mathbf{N O}_{\mathbf{3}}^{-}\right]$ & 0.951 & -0.069 & 0.097 \\
\hline$\left[\mathbf{N H}_{4}^{+}\right]$ & -0.586 & 0.033 & 0.715 \\
\hline$[\mathbf{N T}]$ & 0.841 & -0.221 & 0.403 \\
\hline$\left[\mathbf{P O}_{4}^{3-}\right]$ & 0.207 & 0.807 & -0.338 \\
\hline$[\mathbf{P T}]$ & 0.131 & 0.785 & 0.439 \\
\hline
\end{tabular}


From Figure 4 it results that $F_{1}$ represents $40,32 \%$ of the variance and is expressed towards its positive pole by $[\mathrm{NT}],\left[\mathrm{NO}_{3}^{-}\right],[\mathrm{PT}]$ and $\left[\mathrm{PO}_{4}^{3-}\right]$ that have a good correlation between them. Remark a strong correlation between $\left[\mathrm{NO}_{3}^{-}\right]$and $[\mathrm{NT}]$ on one hand, and between $\left[\mathrm{PO}_{4}^{3-}\right]$ and $[\mathrm{PT}]$ on another hand. $\left[\mathrm{NH}_{4}^{+}\right]$is oriented towards its negative pole.

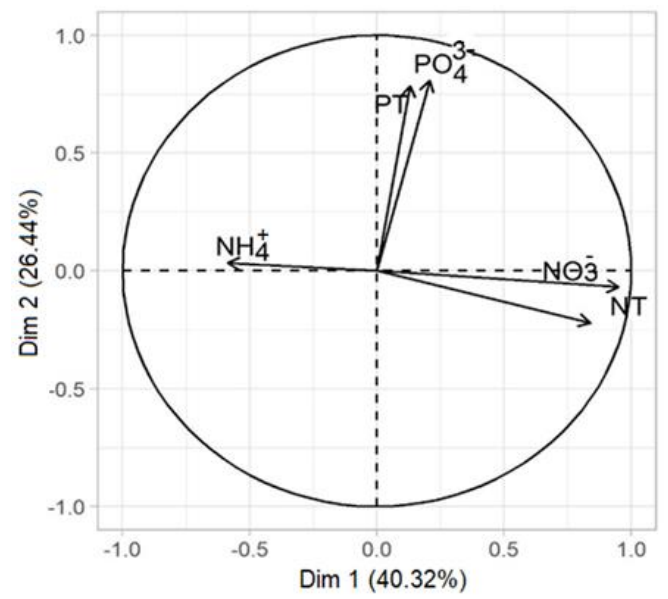

Fig.4. The representation of variables in the factorial plane $(1,2)$,

$F_{2}$ represents $26,44 \%$ of the variance and is defined by $\left[\mathrm{PO}_{4}^{3-}\right],[\mathrm{PT}]$ and $\left[\mathrm{NH}_{4}^{+}\right]$. There is a strong correlation between $[\mathrm{PT}]$ and $\left[\mathrm{PO}_{4}^{3-}\right] .\left[\mathrm{NO}_{3}^{-}\right]$and $[N T]$, strongly correlated, are oriented towards the negative pole of $F_{2}$.

Analogous, the representation of the variables in the factorial plane $(1,3)$ shows that $\mathrm{F}_{1}$ représents $40.32 \%$ of the variance and variance and is expressed towards its positive pole by $[\mathrm{PT}],[\mathrm{NT}],\left[\mathrm{NO}_{3}^{-}\right]$and $\left[\mathrm{PO}_{4}^{3-}\right] .\left[\mathrm{NH}_{4}^{+}\right]$is oriented towards its negative pole. $\mathrm{F}_{3}$ represents $19,80 \%$ of the variance, positively expressed by $\left[\mathrm{NH}_{4}^{+}\right],[\mathrm{PT}][\mathrm{NT}]$ et $\left[\mathrm{NO}_{3}^{-}\right]$, and negatively expressed by $\left[\mathrm{PO}_{4}^{3-}\right]$.

Note that the classification was made from the results of the PCA made on the data from Lake Nokoué by keeping only the first three main components. Figure 5 contains the dendrogram obtained after the classification of individuals.

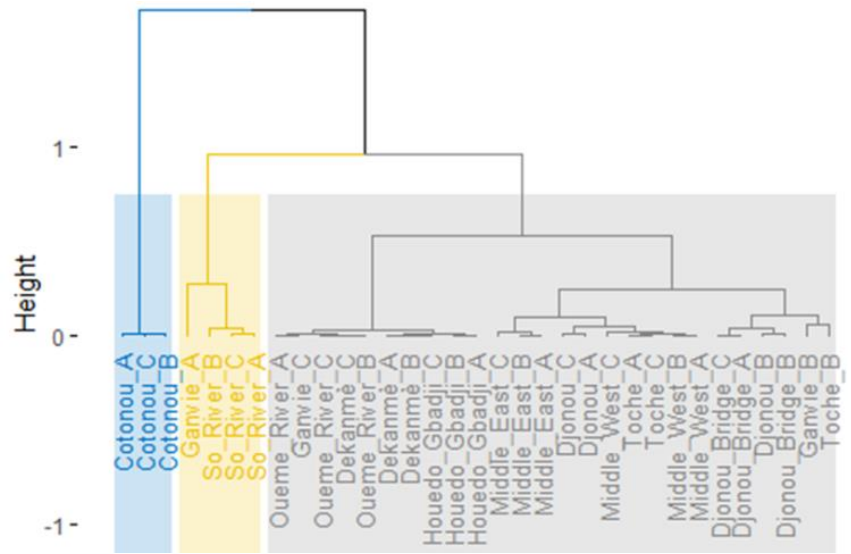

Fig.5. Dendrogram obtained for the individual (sites) classification using the hierarchical clustering 
Given the structure of the dendrogram and the percentage of information explained $(86.56 \%)$ by the first three principal components, we retain three classes (clusters).

Table 4 shows the concentrations that best describe each cluster.

Table 4. The concentrations that best describe each cluster

\begin{tabular}{|c|c|c|c|c|c|c|c|}
\hline Cluster & $\begin{array}{c}\text { Conc. } \\
{[\mathrm{mg} / \mathrm{L}]}\end{array}$ & v.test & $\begin{array}{c}\text { Intra- } \\
\text { group } \\
\text { average }\end{array}$ & $\begin{array}{c}\text { Global } \\
\text { average }\end{array}$ & $\begin{array}{c}\text { Intra- } \\
\text { group } \\
\text { std.dev. }\end{array}$ & $\begin{array}{c}\text { Global } \\
\text { std.dev. }\end{array}$ & p.value \\
\hline \multirow{2}{*}{1} & $\begin{array}{c}{\left[N O_{3}^{-}\right]} \\
(\mathrm{mg} / \mathrm{l})\end{array}$ & -2.68 & 0.11 & 0.16 & 0.064 & 0.15 & $7.31 \mathrm{e}-03$ \\
\cline { 2 - 8 } & $\begin{array}{c}{[P T]} \\
(\mu \mathrm{g} / \mathrm{l})\end{array}$ & -3.1 & 22.64 & 26.88 & 5.18 & 10.95 & $1.94 \mathrm{e}-03$ \\
\cline { 2 - 9 } & $\begin{array}{c}{\left[P O_{4}^{3-}\right]} \\
(\mu \mathrm{g} / \mathrm{l})\end{array}$ & -4.32 & 4.68 & 8.03 & 2.85 & 6.20 & $1.56 \mathrm{e}-05$ \\
\hline \multirow{2}{*}{2} & $\begin{array}{c}{\left[P O_{4}^{3-}\right]} \\
(\mu \mathrm{g} / \mathrm{l})\end{array}$ & 4.05 & 15.88 & 8.03 & 6.19 & 6.20 & $5.16 \mathrm{e}-05$ \\
\cline { 2 - 9 } & $\begin{array}{c}{[P T]} \\
(\mu \mathrm{g} / \mathrm{l})\end{array}$ & 3.69 & 39.5 & 26.88 & 14.14 & 10.95 & $2.25 \mathrm{e}-04$ \\
\hline \multirow{2}{*}{3} & $\begin{array}{c}{\left[N O_{3}^{-}\right]} \\
(\mathrm{mg} / \mathrm{l})\end{array}$ & 5.01 & 0.57 & 0.16 & 0.054 & 0.15 & $5.36 \mathrm{e}-07$ \\
\cline { 2 - 9 } & $\begin{array}{c}{[\mathrm{NT}]} \\
(\mathrm{mg} / \mathrm{l})\end{array}$ & 4.97 & 7 & 2.48 & 0 & 1.62 & $6.54 \mathrm{e}-07$ \\
\cline { 2 - 8 } & $\begin{array}{c}{\left[N H_{4}^{+}\right]} \\
(\mathrm{mg} / \mathrm{l})\end{array}$ & -2.32 & 0.14 & 0.33 & 0.017 & 0.14 & $2.02 \mathrm{e}-02$ \\
\hline
\end{tabular}

The sites on the Ouémé, Dékanmè, Houédogbadji, Djonou and the Toché canal, and a few sites in the middle of the Nokoué Lake are included in the first cluster. The second cluster is mainly made up of sites on the Sô River. Cluster 3 is only made up of the sites in Cotonou.

Examination of Table 4 reveals that cluster 1 is characterized by the concentrations of $\left[\mathrm{NO}_{3}^{-}\right]$, $[\mathrm{PT}]$ et $\left[\mathrm{PO}_{4}^{3-}\right]$; the concentrations $\left[\mathrm{PO}_{4}^{3-}\right]$ and $[\mathrm{PT}]$ best describe cluster 2, whereas the third cluster is best explained by the concentrations of $\left[\mathrm{NO}_{3}^{-}\right],[\mathrm{NT}]$, and $\left[\mathrm{NH}_{4}^{+}\right]$.

The variations of the ammonium are identical at all the sites of the first cluster. Indeed, the anthropogenic activities (wastewater discharges, agriculture, etc.) taking place in the watershed facilitate the migration of this pollutant by surface runoff from different tributaries of the Nokoué Lake (Djonou and Toché).

On the sites of cluster 2, phosphorus undergoes the oxidation phenomena and is transformed into orthophosphate. The same variation of nitrate and Kdjeldhal nitrogen is observed in cluster 3 . In fact, in an oxygenated medium, nitrogen undergoes the same transformations as phosphorus to lead to the formation of nitrate, nitrite, and ammonium.

\section{CONCLUSIONS}

Around the world, water pollution is a general issue, especially given the growing need for water. Surface waters are more and more vulnerable to contamination.

In this article, we applied the PCA to study the series of five pollutants collected from 33 sites in the Nokoué Lake. PCA allowed the visualization and analysis of the correlation 
between the different variables. Also, clustering made it possible to distinguish three groups of sites.

In recognition of the negative impacts of pollutants and the need for integrated management, new approaches must be developed for the management of surface water in Benin to ensure a supply of good quality water.

\section{REFERENCES}

[1] H. H. Soclo (2003). Étude de l'impact de l'utilisation des engrais chimiques et des pesticides par les populations riveraines sur les écosystèmes (eaux de surface, végétaux et faune) des aires protégées (Parcs Nationaux et Zones Cynégétiques). Rapport d'étude. CENAGREF, Bénin.

[2] A. Al-Taani et al. (2021), Contamination Assessment of Heavy Metals in Agricultural Soil, in the Liwa Area (UAE), Toxics, 9(3), 2021, 53

[3] Y. Nazzal et al. (2021), Assessment of metals concentrations in soils of Abu Dhabi Emirate using pollution indices and multivariate statistics. Toxics no.9, 95, doi: 10.3390/toxics 9050095

[4] F. Aonofriesei, A. Bărbulescu, C. S. Dumitriu (2021) Statistical analysis of morphological parameters of microbial aggregates in the activated sludge from a wastewater treatment plant for improving its performances, Romanian Journal of Physics, vol. 66(7-8), 809.

[5] A. Bărbulescu, C. Ș. Dumitriu, Assessing the water quality by statistical methods, Water, 13(8), 2021, 1026, https://doi.org/10.3390/w13081026

[6] A. Bărbulescu, L. Barbeș, C. S. Dumitriu, Statistical Assessment of the Water Quality Using Water Quality Indicators - Case study from India. In: A. Vaseashta, C. Maftei, Water Safety, Security and Sustainability. Advanced Sciences and Technologies for Security Applications, Springer, 2021, pp. 599-613. https://doi.org/10.1007/978-3-030-76008-3_26. (ISBN 978-3-030-76007-6).

[7] A. Bărbulescu, A. Dani (2019) Statistical analysis and classification of the water parameters of Beas River (India), Romanian Reports in Physics, vol. 71, no. 4, art.716.

[8] A. Bărbulescu, Y. Nazzal, F. Howari (2020), Assessing the groundwater quality in the Liwa area, the United Arab Emirates, Water, vol. 12(10), 2816, https://doi.org/10.3390/ w12102816

[9] A. Bărbulescu, L. Barbes (2021), Statistical methods for assessing the water quality after the treatment on a Sequencing Batch Reactor, Science of The Total Environment, vol. 752, 141991, https://doi.org/10.1016/j.scitotenv.2020.141991

[10] M. Mihăilescu, et al. (2021), Full Factorial Design for Gold Recovery from Industrial Solutions. Toxics no. 9, 111. doi: 10.3390/toxics9050111.

[11] S. Aw, E.B.Z. N'goran, S. Siaka, and B. Parinet (2011), Intérêt de l'analyse multidimensionnelle pour l'évaluation de la qualité physico-chimique de l'eau d'un système lacustre tropical: cas des lacs de Yamoussoukro (Côte d'Ivoire). Journal of Applied Biosciences, vol. 38, pag.2573-2585.

[12] E. J. Zandagba (2017), Gestion Intégrée des Ressources en eau: Fonctionnement hydrodynamique et qualité physico-chimique du lac Nokoué. Thèse de doctorat en Hydrologie et gestion intégrée des ressources en eau. Université d'Abomey-Calavi. Faculté des sciences.176p. 
[13] P. M. Gnohossou (2006), La faune benthique d'une lagune Ouest Africaine (le lac Nokoué au Bénin), diversité, abondance, variations temporelles et spatiales, place dans la chaine tropique. Thèse de Doctorat, INP de Toulouse, France, 2006, 184p.

[14] P.-L. Gonzalez, L'Analyse en Composantes Principales (A.C.P.) [Online], available at https://maths.cnam.fr/IMG/pdf/A-C-P-.pdf

[15] C. Aggarwal, C. K. Reddy(2007), Data Clustering. Algorithms and Applications, CRC Press, pag. 88-111.

[16] S. Le, J. Josse, F. Husson (2008). FactoMineR: An R Package for Multivariate Analysis, Journal of Statistical Software, vol. 25(1), pp. 1-18. DOI: 10.18637/jss.v025.i01

\section{Note:}

Deguenon Judicaël - Ecole Polytechnique d'Abomey-Calavi (EPAC), Benin (e-mail: tjudy73@gmail.com)

Deguenon Jean - UNESCO Chair In Mathematical Physics and Applications (ICPMA), University d'Abomey-Calavi, Benin (e-mail: jeandeguenon2016@gmail.com)

Dumitriu Cristian Ștefan - Transilvania University of Brașov, Faculty of Civil Engineering, 5, Turnului Str, 900152, Braşov, Romania (corresponding author to provide e-mail:alinacristiandumitriu@gmail.com) 